\title{
EL MILAGRO EN LA CONSTRUCCIÓN DEL CUlTo a NuEstra SEÑora de COPACABANA (VIRREINATO DEL PERÚ, 1582-1651)1
}

Julia Costilla ${ }^{2}$

\section{* Introducción y consideraciones PRELIMINARES}

\begin{abstract}
Resumen
Se indaga en el proceso de construcción del culto a la Virgen de Copacabana en el virreinato peruano, contemplando especialmente el papel que cumplió en él el milagro, y desde qué lugar -o lugares- se elaboró y reelaboró dicho culto. Para ello, se intenta identificar a los actores que participaron en la creación y difusión de esta devoción, y a sus respectivos intereses y objetivos; como también a quiénes intervinieron en los acontecimientos milagrosos atribuídos a la imagen de la Virgen.
\end{abstract}

Palabras claves: Virgen de Copacabana - milagros - religiosidad colonial.

\section{Abstract}

The aim of this paper is to trace the process of the cult of the Virgin of Copacabana in the Viceroyalty of Peru, focusing on the role it played in the miracle, and from wich place, or places, the cult was developed and re-developed. For this, we attempt to identify the actors involved in the creation and dissemination of the cult and their respective interests and objectives, and also, who were involved in the miraculous events attributed to the Virgin image.

Key words: Virgin of Copacabana - miracles - colonial religiosity. Recibido: noviembre 2009. Aceptado: marzo 2010.
Uno de los santuarios marianos más tempranos de los erigidos en América, es el de Nuestra Señora de Copacabana, situado en la ciudad homónima a orillas del lago Titicaca. ${ }^{3}$ La imagen de la virgen fue entronizada en 1583 y su culto aún continúa desarrollándose. Su importancia ha sido tan relevante que, en 1925, fue consagrada como Madre y Reina de la nación boliviana.

En este trabajo, nos proponemos indagar en el proceso de construcción del culto a la Virgen de Copacabana en el virreinato peruano, contemplando especialmente cuál fue el papel del milagro en dicho proceso y desde qué lugar -o lugares - se elaboró y reelaboró. Trabajando a partir de los relatos de los agustinos Alonso Ramos Gavilán (1976 [1621] ) y Antonio de la Calancha (1972 [1639-1657] ), trataremos de identificar qué actores y con qué objetivos e intereses participaron en la creación y difusión de esta devoción; quiénes intervinieron en los acontecimientos milagrosos atribuidos a la imagen de la virgen y qué relaciones y tensiones se fueron constituyendo en torno a ese proceso.

El vasto campo de los estudios sobre religiosidad colonial latinoamericana y particularmente del Área Andina, ha convocado a investigadores que desde distintos enfoques (antropológicos, históricos, etnohistóricos, sociológicos, entre otros) analizaron los múltiples y cambiantes procesos que resultaron del encuentro entre

\footnotetext{
1 Una primera versión de este trabajo fue presentada en el II Simposio Internacional sobre Religiosidad, Cultura y Poder, en agosto de 2008, organizado por el GERE-PROHAL (Instituto Ravignani, Universidad de Buenos Aires).

2 Instituto de Ciencias Antropológicas, Universidad de Buenos Aires. Juan B. Vago 774, Temperley (1834), Buenos Aires, ARGENTINA. Email: juliacostilla@hotmail.com

3 Utilizamos el concepto de santuario como un tipo particular de ermita que se distingue por una serie de características: es un lugar cuyo emplazamiento tiene un significado sagrado, donde suceden milagros y se depositan ofrendas. Atrae devotos de distintas poblaciones - principalmente enfermos-, y tiene una especial consideración en la devoción de las personas (Christian 1991: 97).
} 
ritos y simbologías del cristianismo y prácticas y representaciones de raigambre precolombina (Rostworowski 1986; Bouysse-Cassagne 1997, 2004; Salles-Reese 1997; Marzal 1999; Estenssoro 2003, 2005; Fogelman 2003, entre otros). ${ }^{4}$ Todos ellos profundizaron, en mayor o menor medida, en las vicisitudes del accionar evangelizador y en las adaptaciones y resistencias de las sociedades nativas. No obstante, si bien los milagros son fenómenos frecuentemente mencionados en relación a estos temas, pocos trabajos han problematizado antropológicamente su papel dentro de tales procesos. ${ }^{5}$

En este sentido, la hipótesis con la cual abordamos el análisis de este culto andino, es que los milagros pueden actuar como herramientas simbólicas esgrimibles estratégicamente desde distintos sectores y actores de la sociedad para generar mecanismos de cohesión social, acceder a ciertos espacios y beneficios o legitimar posiciones. Intentaremos contrastar nuestro argumento recurriendo a las dos crónicas coloniales más profusas en la narración de prodigios atribuidos a esta imagen mariana. En el primer apartado haremos una breve introducción a la problemática del milagro, para luego detenernos sobre las fuentes empleadas y finalmente contextualizar el culto colonial a la Virgen de Copacabana.

\section{Entre signos y símbolos: Consideraciones sobre el milagro}

La definición teológica respecto a la noción cristiana de "milagro", establece que no es una mera acción extraordinaria sino un signo de Dios: un hecho excepcional que significa una intervención especial de la virtud divina, y donde la verdad religiosa tiene un lugar central en tanto sustento empírico (Covarrubias Orozco 2006 [1611]; Costilla 2007). ${ }^{6}$ En tanto signo de Dios, el milagro se

\footnotetext{
4 Para una mayor problematización sobre estos temas, ver Costilla (2008-2010).

5 Destacamos aquí el trabajo de Lorandi y Schaposchnik (1990) sobre la Virgen del valle de Catamarca; para las referencias a tipologías y funciones del milagro, ver Bouysse-Cassagne (1997, $2007 \mathrm{Ms}$ ); Estenssoro (2003, 2005) y las consideraciones de Marzal (1999) sobre la religiosidad colonial peruana.

6 Según la definición de Ramos Gavilán (1976 [1621]: 132) es “... cosa imposible a los humanos ojos, que deja atrás la fuerza de la naturaleza, hecho en orden de manifestar la divina gracia, la verdad y virtud en utilidad de la Iglesia...".
}

vuelve una herramienta clave para la construcción y consolidación de cultos cristianos, sumamente funcionales a los intereses de la Iglesia. Pero cuando el prodigio interviene en una determinada realidad social -siendo interpretado y manipulado desde distintas instancias de la sociedadparece dejar de ser un mero signo de Dios para volverse también, un "símbolo". Es, por tanto, una entidad polémica de interpretar, capaz de condensar y unificar múltiples y dispares significados tras su sentido más manifiesto (Costilla 2007).

Contemplando las diferencias entre el significado teológico del milagro y el sentido más coloquial en el que los fieles lo toman -que puede o no coincidir con el primero-, consideramos válido discernir tres posibles definiciones o lecturas para estos fenómenos entendidos como construcciones sociales.? Una definición teológica (el milagro como signo de Dios), una "popular" (el milagro como hecho improbable o inesperado) y una hermenéutica que, en tanto definición desde la perspectiva del investigador, corresponde a nuestro planteamiento del milagro como símbolo. Sin duda, por el tipo de fuentes que utilizaremos, los prodigios relatados corresponden a una lectura teológica de los sucesos, sobre la cual construiremos nuestra interpretación hermenéutica.

Para el análisis de los milagros como acontecimientos concretos, estableceremos una distinción operativa en función de las características que presentan y a quién manifiestan estar dirigidos. Es decir, si son impersonales, individuales o colectivos. Los "impersonales" serían aquellos que la imagen sagrada realiza sobre sí misma o en relación a otros elementos, pero que no atañen directamente a una persona o personas. Los "individuales", aquellos que la imagen obra sobre algún sujeto en su propio beneficio y/o el de sus allegados. Los "colectivos", por su parte, serían los prodigios que la imagen efectúa a favor de un determinado grupo de individuos como totalidad. Esta clasificación inicial se establece identificando a quienes se supone que el milagro va dirigido. Sin embargo, un mismo suceso puede ubicarse en distintas categorías según la pro-

\footnotetext{
7 La definición "popular" de milagro es aquella que nace de las propias percepciones de los actores, los devotos lo construyen como un hecho que excede lo posible o esperable pero que puede no ser entendido por la Iglesia como un signo de Dios (Marzal 1999: 167).
} 
fundidad con que se analicen sus significados y considerando quiénes pueden ser afectados indirectamente. En relación con nuestra hipótesis, aplicar esta distinción nos permite analizar más sistemáticamente la variabilidad de interpretaciones respecto a un mismo suceso prodigioso, como también estimar posibles correspondencias y vinculaciones entre tipos de milagros y sus usos estratégicos.

¿Pero hasta dónde es posible, a partir de las fuentes que a continuación describiremos, reconocer esos usos estratégicos y contrastar nuestra propuesta del milagro como símbolo en relación a este caso particular? En este sentido, consideramos que aunque la identificación de usos del milagro no sea directamente accesible a partir de fuentes históricas, un acontecimiento milagroso, en tanto construcción social, actúa siempre como un símbolo, capaz de generar y canalizar distintos significados y de ser esgrimido para diversos intereses (p.e., Mujica 2001).

\section{Las fuentes: Alonso Ramos Gavilán y Antonio de la Calancha}

Como ya anticipamos, las crónicas de estos dos religiosos agustinos serán nuestros testimonios principales, de manera que el panorama sobre los hechos y procesos sociales a analizar estará mediatizado por las miradas, objetivos y expectativas de ambos cronistas.

En general, los frailes de la Orden de San Agustín han sido caracterizados por la especial importancia que le daban al culto externo, a las imágenes y al establecimiento de cofradías de la virgen en los lugares donde se establecían. Distinguidos por la ejemplaridad de su comportamiento y su rigor disciplinar, generaron una misión evangelizadora inusual, distinta de las iniciadas por las demás órdenes, especialmente por una mayor apertura hacia las expresiones indígenas de piedad cristiana (Salles-Reese 1997). ${ }^{8}$ Fue en el marco de esta tradición

8 Según Villarejo (1965) la primera generación de agustinos asentados en Perú fue de una notable expansión espiritual por sus numerosos conventos, doctrinas y misiones, como también por los cargos que ocupaban los religiosos. Hacia fines del s. XVI, la importancia de esta orden fue decisiva para el virreinato. Pero luego, con el aumento de las riquezas, cargos y grados académicos comenzó la lucha política y la relajación de las costumbres "santas" instituidas por los primeros agustinos. misional, y en relación a sus propias trayectorias personales, que estos autores pudieron interpretar la realidad religiosa y política de la región andina.

La obra de Ramos Gavilán es una de las primeras y más completas descripciones sobre la región del Collao. El autor nació en Huamanga, en 1570, fruto de una relación ilegítima entre dos criollos naturales de esa ciudad. Formado en el convento de San Agustín, tomó el hábito en 1588, y luego de extensos viajes por el norte y centro de Perú, fue enviado en 1616 como doctrinero al curacazgo de Omasuyo, estableciéndose en el convento agustino de Copacabana a comienzos de 1618. Los datos que obtuvo para la elaboración de su trabajo fueron producto de un estudio minucioso de la documentación del archivo del convento, de sus lecturas de los primeros cronistas de Perú, y de sus conversaciones con curaca y ancianos indígenas de la región, posibilitadas por su conocimiento de las lenguas quechua y aymara. De ahí que su obra, publicada en 1621, haya sido considerada tanto por los cronistas contemporáneos como por los investigadores actuales, como un trabajo serio, fidedigno, acucioso y detallado sobre la historia religiosa de la región (Muñoz Reyes cit. en Ramos Gavilán 1976 [1621]).

Antonio de la Calancha nació en la ciudad de La Plata en 1584, hijo de españoles de muy buena posición social y económica. Ya de muy joven ingresó al convento agustino de esa ciudad, y luego de ordenarse como sacerdote fue enviado a Lima para continuar su carrera eclesiástica. Una vez graduado como Doctor y como Maestro de la Orden, se desempeñó como catedrático y predicador en esta ciudad, en Cusco y en Potosí, donde ocupó también importantes cargos eclesiásticos. Gracias a sus "cualidades y excepcionales dotes" (Calancha 1972 [1639]: XXXIII) para la investigación histórica, recogió a lo largo de sus viajes a través del virreinato peruano valiosa información archivística y testimonial que le permitió elaborar una de las crónicas más valoradas y difundidas sobre la historia de Perú en general y de los agustinos en particular. El primer tomo de su obra, publicado en 1639, se basó fundamentalmente en el citado trabajo de Ramos Gavilán. El segundo, luego de su repentina muerte en 1654, fue publicado en 1657 con la continuación y colaboración del Padre Bernardo de Torres. ${ }^{9}$

9 Más allá de la importancia de su trabajo, Calancha ha recibido 
Dado que ambos cronistas manifestaban una profunda y sincera devoción por la Virgen de Copacabana, se debe considerar la influencia de sus intereses y de su subjetividad en la narración de los milagros. Ramos Gavilán profundizó su devoción por la virgen en el pueblo de Copacabana a partir del contacto diario con los habitantes y devotos a quienes atendía como vicario. Calancha, por su parte, recibió durante su noviciado en La Plata una primera impresión concreta de los poderes de Nuestra Señora de Copacabana, y años más tarde, luego de una experiencia personal muy fuerte con esta imagen, se decidió a dedicarle como tributo por su milagro la composición de una obra sobre su historia (Calancha 1972 [1639]: 541-544; Ramos Gavilán 1976 [1621]; Van Den Berg 2002).

Si bien nos centraremos en esta ocasión en la particular lectura de los hechos que estos religiosos registraron, ambas fuentes deberán ser complementadas con otros testimonios que puedan arrojar luz sobre la percepción local o nativa de las sacralidades que aquellos describen. ${ }^{10}$ No obstante, y al menos en una primera instancia, ameritan ser exploradas en detalle por la profusa cantidad de datos que ofrecen, en especial en cuanto a los milagros iniciales de esta imagen de la Virgen.

\section{Contextualización histórica y simbólico-religiosa de Copacabana}

El pueblo colonial de Santa Ana de Copacabana, donde se originó este culto, estaba situado en el área del Collao dentro del Collasuyo antiguo cuadrante sur del Tawantinsuyo (Figura 1). Ubicado sobre la península más grande del lago Titicaca, el espacio geográfico de Copacabana presentaba para la población prehispánica un impor-

fuertes críticas de parte de reconocidos historiadores peruanos contemporáneos como Raúl Porras Barrenechea (cit. en introducción a Calancha 1972 [1639]: 36-37), quien lo describe como el cronista conventual más representativo, por reunir las características típicas de este tipo de autores: despreocupación por la fidelidad histórica, credulidad, propensión a la milagrería, finalidad edificadora y moralizadora, y parcialidad del relato.

${ }^{10}$ Referimos aquí a aquellas investigaciones que proponen, para el estudio de las sociedades andinas coloniales, el uso de otro tipo de soportes y sistemas de registro no escritos (p.e., Gisbert 1984; Salomon 1994; Martínez 2000; Estenssoro 2005; Abercrombie 2006). tante significado histórico y espiritual en tanto lugar sagrado. ${ }^{11}$ Como espacio neurálgico en la geografía religiosa andina, la región del Titicaca experimentó una permanente reconfiguración simbólica en sus distintas etapas históricas. Durante el período previo a la expansión incaica, el lago era el centro religioso de los señoríos colla (o aymara), que desarrollaron en torno a él su culto al Sol, a la Luna y a huaca como la Peña Sagrada en la isla Titicaca (Báscones 1998). ${ }^{12}$ Con la llegada de los primeros soberanos incaicos a la región, se erigió en esa isla el templo del Sol y se centralizó el culto en torno a esta deidad. Se edificó además el adoratorio de la Luna, señalada como mujer o coya del Sol, en la isla homónima o isla Coati, y se sacralizaron los lugares ubicados en puntos estratégicos de la península, convirtiendo a este espacio en el centro espiritual del imperio, el "centro del mundo" y el lugar de origen del universo. Así, para el servicio de la casa del Sol, fueron ubicados en Copacabana indígenas mitimaes de distintas provincias (Espinoza 1972). Otras importantes huaca locales como Copacati y Copacabana, ligadas al agua, a la fertilidad, a los peces y a la sensualidad, resultaron desplazadas y subordinadas simbólicamente a la deidad solar (Ramos Gavilán 1976 [1621]; Salles-Reese 1997; Báscones 1998; Luján López 2002). Asimismo, antiguos personajes como Tunupa, deidad aymara compleja y polimorfa ligada al fuego y a las aguas, pasaron a ocupar en la reinterpretación inca un lugar secundario y subordinado a Viracocha, divinidad creadora y civilizadora, como reflejo del sometimiento de los señoríos aymara a la dominación cusqueña (Rostworowski 1986; Wachtel 2001).

Ahora bien, respecto del marco sociopolítico previo al surgimiento del culto a la Virgen de Copacabana, debemos retrotraernos hasta la tercera y cuarta década del s. XVI, en torno a ciertos acontecimientos clave que fueron marcando el curso del proceso de conquista y

${ }^{11}$ Para un análisis más profundo sobre la sacralidad y simbolismos prehispánicos del lago Titicaca, sus continuidades y vinculaciones con la religiosidad andina local y el culto a la Virgen de Copacabana, ver Gisbert (1984), Salles-Reese (1997), Báscones (1998), López (1998), Bouysse-Cassagne (2004).

12 Titicaca, cuyo significado sería peña del gato montés o peña del cobre (titi: gato montés o cobre, plomo, estaño; kaka: peña [en Ramos Gavilán 1976 [1621]:46,47]), era el nombre de esta huaca y de la isla grande, conocida luego como la Isla del Sol por el adoratorio incaico. 


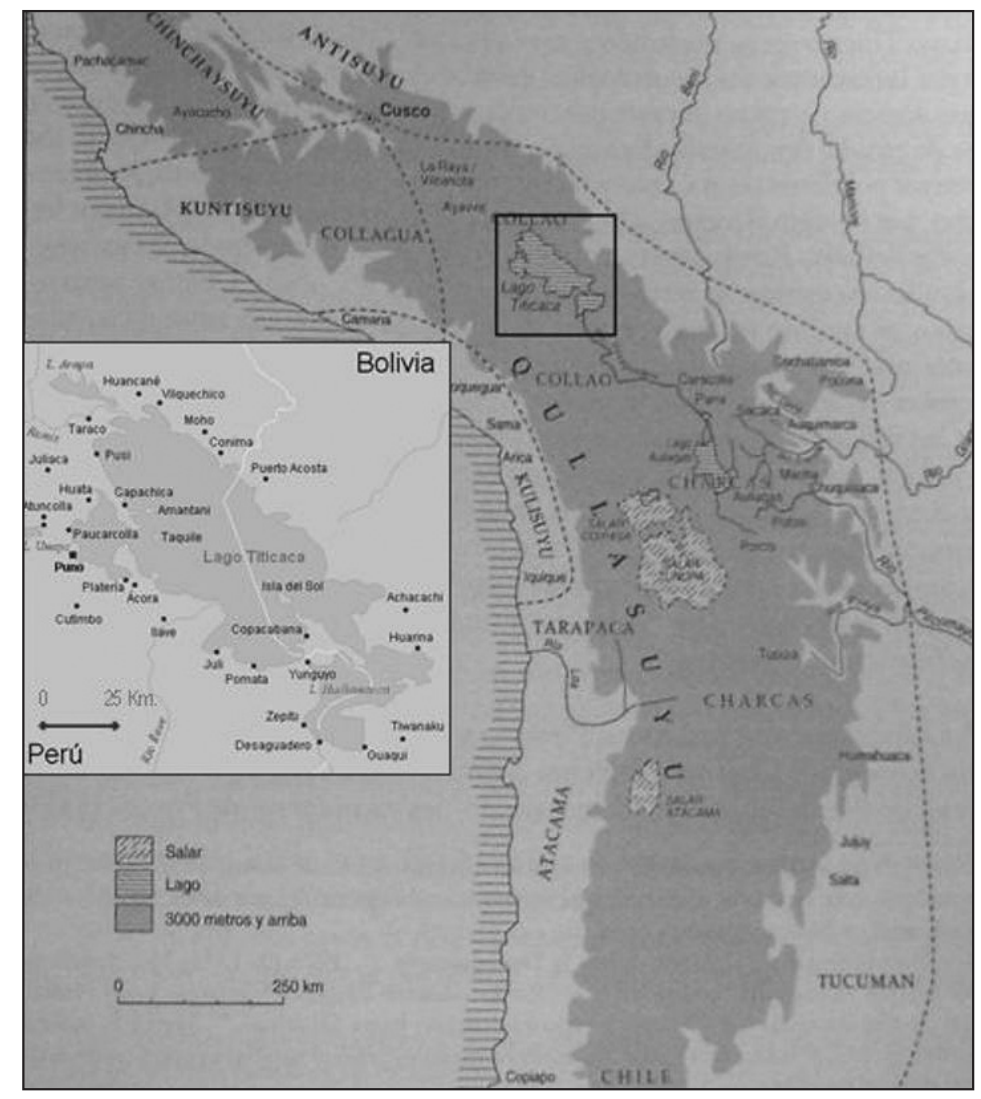

Figura 1. Mapa del antiguo Collasuyo y detalle de lago Titicaca con división política actual (Platt et al. 2006).

colonización en el virreinato. Nos referimos principalmente a las campañas de los hermanos Pizarro hacia el Collasuyo (1538), con el consiguiente descubrimiento de los yacimientos de oro, plata y estaño de la región (Porco en 1538 y Potosí en 1545); a la pacificación de Perú con las acciones del presidente La Gasca (1548); y a las reformas implementadas por el virrey Toledo a partir de 1569 (Platt et al. 2006).

En este contexto, justamente con la entrada de los hermanos Hernando y Gonzalo Pizarro en 1538 -luego de la muerte de Almagro-, se produce la conquista del Collao con la significativa colaboración de Paullo Topa Inka. Este último, hijo menor de Huayna Capac, era el portavoz de la política de rendición en las mejores condiciones posibles, y fue esa la actitud que luego irían adoptando los señores étnicos del Collasuyo tras numerosos enfrentamientos y miles de pérdidas humanas (Medinacelli 2007). Nueve años más tarde, en el marco del refe- rido accionar pacificador de La Gasca, los indígenas del pueblo de Copacabana fueron entregados en encomienda al Licenciado García de León. Dicho pueblo, como indicamos anteriormente, estaba conformado por mitimaes incaicos de naciones distintas, muchos de los cuales, una vez instituida la encomienda, fueron enviados a trabajar a las minas de Carabaya y Potosí (Bauer y Stanish 2001).13 Geográficamente, Copacabana se encontraba en el límite entre las provincias de Chucuito y Omasuyo, constituyendo el "último pueblo de la jurisdicción de Omasuyo, una grande legua del cual está Yunguyo, lugar primero

13 Ramos Gavilán (1976 [1621]) señala 43 naciones distintas: Anacuscos, Hurincuscos, Ingas, Chinchisuyos, Quitos, Pastos, Chachapoyas, Cañares, Cayambis, Latas, Cajamarcas, Guamachucos, Guaylas, Yauyos, Ancaras, Quichuas, Mayos, Guancas, Andesuyos, Condesuyos, Chancas, Aymaras, Lanaguaras, Chumbivilcas, Pabrechilques, Cillaguas, Hubinas, Canches, Canas, Quilvarguaros, Lupacas, Capancos, Pucopucos, Pacajes, Yungas, Carangas, Quillacas, Chichas, Soras, Copayapos, Colliyungas, Guanacos y Huruquillas. 
de la Governación de Chucuito" (Ramos Gavilán [1621]: 1976 [1621]: 12). En 1548 se fundó la ciudad de Nuestra Señora de La Paz y se creó el corregimiento de españoles homónimo. Desde entonces, el corregimiento de indios de Omasuyo, donde se ubicaba Copacabana (hasta ese momento perteneciente a la jurisdicción de la ciudad de Cusco), pasó a ser sufragáneo del recién conformado corregimiento de La Paz que, a su vez, fue incluido en la jurisdicción de la Real Audiencia de Charcas en 1559. En la década de 1570, con las reformas del virrey Francisco de Toledo, se produce una reorganización de la península. En 1572, Copacabana se establece como pueblo de reducción a partir de la visita de Pedro Ortíz de Zárate, quien empadronó y tasó a sus habitantes con un total de 5970 pobladores, de los cuales 1041 eran tributarios (953 mitimaes y 88 uros sacados de las islas y orillas del lago) (Espinoza 1972; Ramos Gavilán 1976 [1621]: 8; Bauer y Stanish 2001).

El proceso de evangelización de esta región del Collao también se remonta a los primeros años de la década de 1540, con la llegada del primer cura enviado por Francisco Pizarro a la provincia de Chucuito, Francisco Ruiz. Pocos años después, la doctrina pasó a manos de los dominicos, que llegaron a esta provincia en 1547. Aunque Copacabana fue una demarcación independiente de los Lupaca de Chucuito, las autoridades coloniales dispusieron que los frailes dominicos de Chucuito tuvieran a la península bajo su custodia. Copacabana y el colindante pueblo de Yunguyo fueron entregados a esa orden religiosa para el adoctrinamiento católico, la que se estableció a comienzos de 1550 , erigiendo la primera iglesia y nombrando como patrona y titular a Santa Ana, la madre de la Virgen María (Espinoza 1972). Con la llegada del virrey Toledo, luego de realizadas las visitas generales entre 1569 y 1572 y de registrarse ciertas irregularidades y abusos en el accionar de los dominicos (sumado a la competencia por la mano de obra indígena y a las tensiones entre estos religiosos y los funcionarios coloniales), esta orden fue despojada de sus propiedades y expulsada de Copacabana. De esta forma, la doctrina pasó a estar a cargo de los clérigos.

En términos generales, la Iglesia de Perú avanzaba hacia un mayor grado de institucionalización (Acosta y Vergara 1999), al tiempo que cada uno de los componentes de la sociedad colonial, chocando cada vez más con los intereses de la metrópoli, comenzaba a intentar ampliar su cuota de participación económica y política en un clima de crecientes tensiones y contradicciones. La etapa que se inició en 1581 con el episcopado de Santo Toribio de Mogrovejo y que finalizó en 1670 con el fin de las campañas de extirpación de idolatrías, puede considerarse como la etapa fundacional del proceso de evangelización de Perú, caracterizada por un acercamiento mayor entre la religión católica y la indígena con una mutua aceptación y/o incorporación de sus respectivas formas, ritos y contenidos religiosos (Marzal 1999). Un ejemplo de estos acercamientos para la zona del Titicaca lo encontramos en las narrativas cristianas sobre la presencia de los apóstoles Santo Tomás y San Bartolomé en tierras americanas, cuyas hagiografías, asociadas con el mito "andino" de Tunupa, desplegaban huellas materiales, reliquias, milagros, símbolos y lugares sagrados vinculados a esta región del Collao. ${ }^{14}$ El lago Titicaca, la península de Carabuco, el río Desaguadero, la isla del Sol, eran el escenario de la legendaria trayectoria de este personaje sagrado; historia recreada y resignificada como producción hagiográfica en el contexto cristiano colonial, a través de la articulación en un mismo espacio sagrado, de fragmentos escogidos de tradiciones indígenas y tradiciones cristianas americanizadas. ${ }^{15}$

\footnotetext{
${ }^{14}$ En algunas fuentes Tunupa es presentado como hijo de Viracocha y en otras como deidad creadora opuesta y complementaria de este dios (Rostworowski 1986). Las comillas se deben a la advertencia de Bouysse-Cassagne (1997) respecto de la posible creación colonial de este supuesto mito prehispánico.

${ }^{15}$ De ahí que la figura de Tunupa, asociada a las aguas y al pecado, haya sido identificada con Santo Tomás y San Bartolomé, asociado éste a su vez (en su trayectoria europea y posteriormente en su derrotero andino) al alejamiento de los peligros volcánicos y al sometimiento de los demonios y deidades paganas (Ramos Gavilán 1976 [1621]; Rostworowski 1986; Bouysse-Cassagne 1997). También puede ser identificado con la figura de Cristo, en tanto es presentado como un "hombre nuevo y jamás otra vez visto, el cual hacía grandes milagros y maravillas", como un santo venerado por la población, que terminó siendo perseguido y finalmente martirizado por su predicación (Ramos Gavilán 1976 [1621]: 29). Vinculado a la trayectoria de estos santos, y simultáneo al de la Virgen de Copacabana se desarrolló el culto a la imagen de la milagrosa Cruz de Carabuco, que también implicaba la sustitución de una antigua deidad. Es posible que la huaca de Carabuco, al igual que Copacabana haya sido un destacado centro de culto prehispánico del Titicaca, y que ambas huaca locales hayan sido hábilmente sustituidas por dos imágenes cristianas (Bouysse-Cassagne 1997).
} 
Volviendo a 1572, los curas seculares Antonio de Almeida y el Licenciado Montoro se sucedieron en la administración eclesiástica de Copacabana hasta que, por decisión de la Audiencia de Charcas (y cédula real del 7 de enero de 1588) se otorgó a los agustinos esa doctrina y culto. Ramos Gavilán, destacando las razones providenciales que movieron las acciones y decisiones de las autoridades, describe minuciosamente el proceso jurídico-eclesiástico por el cual la orden resultó elegida para atender el culto a la milagrosa imagen de la Virgen, entronizada en 1583 por el progresivo crecimiento de la devoción (Salles-Reese 1997; López 1998).

Otro hito también significativo de estas últimas décadas del s. XVI, cuyas implicancias debemos considerar en el análisis del nacimiento del culto a la Virgen de Copacabana, es el III Concilio Limense, llevado a cabo entre los años 1582 y 1583 . Dado que uno de sus temas principales fue la promoción religiosa y social del indígena, las disposiciones conciliares estuvieron orientadas a mejorar no solo la enseñanza de la fe cristiana sino también la manera en que los naturales eran tratados por los distintos representantes eclesiásticos. Finalmente, en relación con el contexto religioso general, debemos tener en cuenta que a lo largo del s. XVII, en el marco de las rivalidades con los protestantes, la iglesia católica promovió fervientemente el culto mariano identificándose con la imagen de la Virgen Madre. De manera que existía ya desde las autoridades metropolitanas una preocupación manifiesta por fomentar esta devoción en forma oficial (Fogelman 2003).

Comenzaremos con un análisis de las primeras manifestaciones de la imagen sagrada, hasta la llegada de los agustinos a Copacabana en 1589, y luego trabajaremos con esta segunda etapa de multiplicación de milagros, hasta 1651. Dentro de este segundo período, describiremos la difusión y extensión de la devoción a esta imagen mariana en otras áreas del Virreinato, deteniéndonos particularmente en la ciudad de Lima. Por último, consideraremos cuáles son los usos y apropiaciones de lo religioso en general, y del milagro en particular, que se observan durante el proceso de consolidación del culto.

\section{* Surgimiento del culto en Copacabana:}

EL MILAGRO A FAVOR DE LOS INDÍGENAS (1582-1589)

Como acabamos de anticipar, el panorama general que se percibe en Copacabana para el momento en que suceden los primeros milagros (1582-1583), es el de una sociedad multiétnica con una población indígena muy heterogénea, con un alto componente de descendencia incaica y con un gran porcentaje de antiguos mitimaes, tanto unos como otros poco dispuestos a perder sus anteriores prerrogativas y libertades. ${ }^{16}$ Según Ramos Gavilán ([1621]: 1976 [1621]: 43), la mayoría de las naciones representadas por estos mitimaes ya se encontraban desmedradas, y las únicas cuatro que se mantenían en aumento eran:

“...los Ingas, los Lupacas, Chinchaysuyos y aún también los Aymaras, que con los Collas y Uros, hacen la población que al presente está repartida en tres gobernaciones, Anantayas, Hurinsayas y Uros" (1976 [1621]: 43).

La división tradicional entre Anansaya y Urinsaya, deriva de las posiciones jerárquicas vinculadas al principio organizativo, social y cósmico, presente en muchas sociedades andinas, y basado en la dualidad arriba/abajo. Ambos términos correspondían a las dos parcialidades en las que las sociedades se dividían, ocupando la de arriba, Anansaya, una posición de preeminencia sociopolítica por sobre la de abajo, Urinsaya (Rostworowski 1986; Platt et al. 2006). En Copacabana, se integraban en esta parcialidad Anansaya los descendientes de aquella élite incaica cusqueña que Tupac Inka había enviado allí para el control y gobierno de las naciones trasplantadas (Ramos Gavilán 1976 [1621]; Medinacelli 2007). Efectivamente, si bien el patrón andino tradicional establecía que en la mitad Urinsaya se agrupaban los forasteros y advenedizos, con la reestructuración impuesta por los incas, los recién llegados tomaron el lugar de privilegio, la mitad Anansaya, que antes correspondía a los indios locales, al tiempo que estos últimos pasaron a ser clasificados como Urinsaya (Ramos Gavilán 1976

\footnotetext{
${ }^{16}$ Puesto que habían sido trasladados allí para el servicio de la casa del Sol, estaban liberados de cualquier otra obligación, tributo u ocupación (fundamentalmente de acudir a las mitas). De allí que, quienes posteriormente trabajaron en la sacristía y en los ministerios del santuario, exigieran los mismos fueros y privilegios.
} 
[1621]: 34; MacCormack cit. en Salles-Reese 1997). De ahí que los curaca principales que se sucedieron en Copacabana, antes y durante el desarrollo del culto a la virgen, pertenecían a las panaca incaicas. Dentro de este grupo de élite, destacamos la figura de Francisco Tito Yupanqui, el escultor de la imagen de la virgen, quien fue uno de los hijos del Inka Paullu, conocido por su papel como colaborador de los españoles en las primeras entradas al lugar y como el primer Inka cristiano (Medinacelli 2007) (Figura 2). ${ }^{17}$

\section{Los primeros milagros}

Como ya señalamos, fue precisamente en el interregno secular que transcurrió entre la expulsión de los dominicos y la llegada de los agustinos, que la imagen de la Virgen comenzó a manifestarse. Según las crónicas, en un año de heladas y mal tiempo, los indígenas principales de Copacabana, aconsejados por el cura Montoro, se decidieron a poner la suerte de sus cosechas en manos de algún santo intercesor a través de la fundación de una cofradía. Mientras que la mitad Urinsaya, apoyada por el clérigo, consideraba que esta institución debía fundarse en honor a San Sebastián, la parcialidad Anansaya proponía hacerlo a nombre de Nuestra Señora de la Candelaria, y al no poder llegar a un acuerdo acerca de qué imagen elegir, la obra no prosperó (Calancha 1972 [1639]; Ramos Gavilán 1976 [1621]).

En medio de esa disputa, Francisco Tito Yupanqui se decidió a elaborar una imagen de la Virgen de la Candelaria para su pueblo. Él ya había realizado una imagen para la iglesia que el padre Almeida había aceptado colocar junto al altar, pero su sucesor Montoro le ordenó quitarla por su aspecto tosco e "irrisorio" (Calancha 1972 [1639]; Ramos Gavilán 1976 [1621]). Con la intención de perfeccionarse como pintor, se dirigió a Potosí junto con su hermano Felipe de León donde, el 4 de junio de 1582, comenzó a tallar una imagen "de bulto" de la virgen. Durante su estadía como aprendiz, Francisco se encontró con el gobernador de la mitad Anansa-

\footnotetext{
${ }^{17}$ Existen certeros indicios acerca de que el escultor de la imagen sería hijo de Paullu. Por un lado, lo afirma Ramos Gavilán (1976 [1621]: 189), y lo apoyan otros datos sobre la descendencia de Paullu en Copacabana a partir de su unión marital con una de sus hermanas (Bauer y Stanish 2001; Medinacelli 2007).
}

ya, Alonso Viracocha Inka, quien había viajado a Potosí con su hermano Pablo. Luego de discutir qué podían hacer para establecer la cofradía a pesar de la oposición de la mitad Urinsaya, resolvieron viajar a la ciudad de La Plata para gestionar la licencia para fundarla. Antes de partir, Francisco decidió adjuntar a la petición una imagen en lienzo de la virgen que estaba tallando, imaginando que con ella conseguirían la aprobación del obispo y él obtendría una licencia para pintar y entallar imágenes. Como en lugar de esto recibieron críticas y burlas, mientras el gobernador y su hermano continuaban con la gestión en La Plata, Francisco retornó a Potosí a terminar con la imagen "de bulto". Antes de llevarla a su pueblo, se quedó unos meses en la ciudad de La Paz para perfeccionarla con la ayuda de un español que

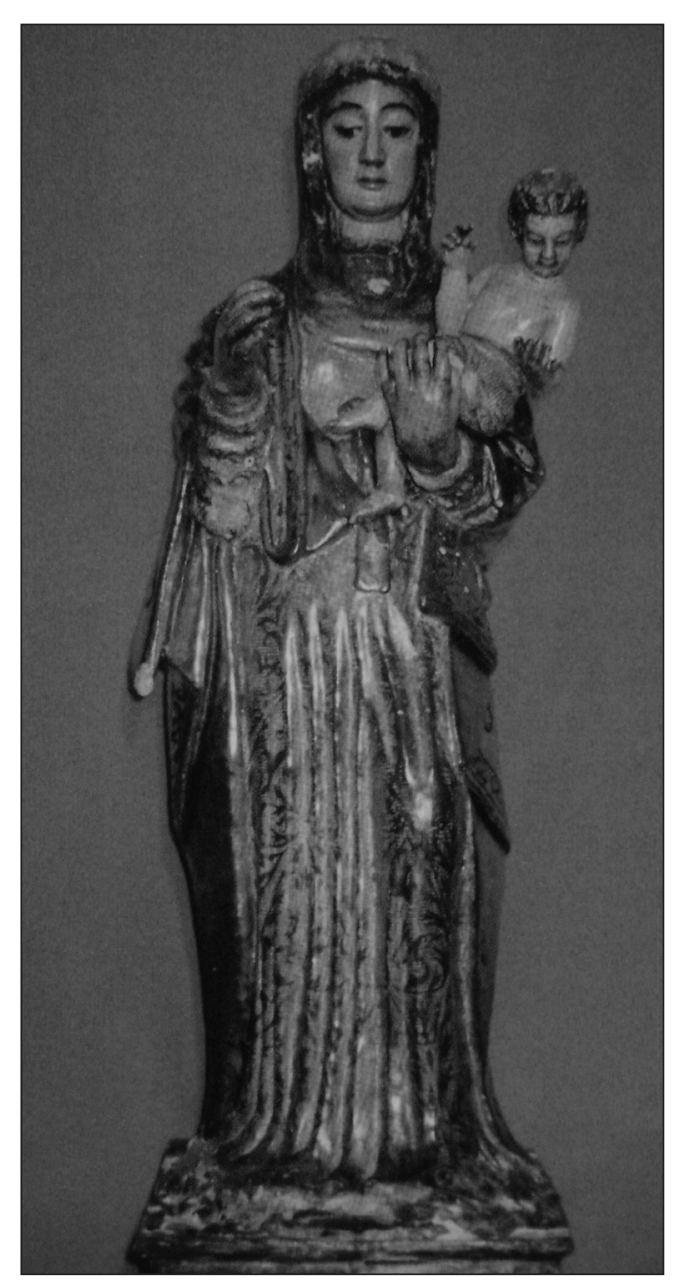

Figura 2. Virgen de Copacabana. 
doraba un retablo del convento de San Francisco. Cuando Alonso y Pablo llegaron a La Paz con la noticia de haber conseguido la ansiada licencia, Francisco ya tenía la imagen terminada, pero al regresar el gobernador a Copacabana encontró que los de la parcialidad Urinsaya no iban a aceptarla por no ser de factura española y por haber sido objeto de burlas. Siendo advertido de este rechazo, Francisco se dispuso a venderla (Calancha 1972 [1639]; Ramos Gavilán 1976 [1621]).

Fue en ese momento cuando la imagen realizó su primer milagro. Un milagro que generó el desarrollo del culto, y que fue, como suele suceder en estos casos, un prodigio impersonal. Estando todavía el escultor en el convento de San Francisco de la ciudad de La Paz, un religioso que tenía la imagen en su celda comenzó a ser deslumbrado por unos rayos que salían de ella cada vez que entraba en su habitación. Al enterarse de este episodio -y como, no obstante, Francisco continuó con sus tratativas para vender la imagen - el corregidor de Omasuyo y Copacabana, Jerónimo Marañón, que estaba en esos días en La Paz, ordenó que no fuese vendida y que debía retornar a Copacabana, asegurándole a su dueño que sería aceptada. Viendo la actitud del corregidor, el gobernador de Urinsaya, Diego Churatopa, quien también estaba en la ciudad, decidió llevarla él mismo a su pueblo. Ya camino a Copacabana, en San Pedro de Tiquina, Churatopa y los indígenas que lo acompañaban se encontraron con el padre Montoro, y éste también recibió con gusto la imagen a pesar de haber estado en un principio a favor de la mitad Urinsaya. La instaló en el altar de la capilla de Tiquina donde permaneció hasta la víspera de la fiesta de la Candelaria, cuando el corregidor ordenó que fueran a buscarla para llevarla a Copacabana. Fue así como el 2 de febrero de 1583 fue llevada en solemne procesión hasta la iglesia de Copacabana, donde se encontraban el corregidor y algunos españoles que lo acompañaban. En ese momento también se constituyó la cofradía que tanto deseaban los de Anansaya, asentándose por miembros “...todos, no siendo los postreros los Urinsayas, que tan primeros habrían sido en su contradicción..." (Ramos Gavilán 1976 [1621]:123). Asimismo, agrega el autor que

"...fue cimbra de la devota cofradía, para levantar alto su edificio asentarse por cofrades el Corregidor, y el Cura, no siendo cortos en sus limosnas; cuyo cristiano celo y devoto ejercicio, acompañó después el religioso hecho, y digno de perpetuas me- morias, que el Padre Diego de Torres, Rector del colegio de la Compañía de Jesús de Juli, con toda su religiosa Compañia, hizo en asentarse por cofrades, prometiendo cada año una misa por los cofrades" (Ramos Gavilán 1976 [1621]: 123; subrayado es nuestro).

Una vez asentada la imagen, los próximos tres prodigios que realizó, uno individual, uno impersonal y uno colectivo, actuaron para su consolidación y mayor aceptación entre los habitantes de Copacabana. El primero, a partir del cual según Ramos Gavilán "empezaron los fieles a venerar la Santa Imagen", se produjo ese mismo 2 de febrero de 1583, cuando una cruz de bronce cayó sobre el corregidor mientras éste sacaba el guión para acompañar a la imagen. La admiración que causó entre los presentes que "con ser pesada la cruz no le hizo daño alguno", llevó a que consideraran al hecho como un "milagro" (Ramos Gavilán 1976 [1621]: 124).

El segundo prodigio, también en 1583 , se destaca por ser el primero que la Virgen hizo en su propia imagen. Cuando el cura mandó al escultor que la modificara para que, al colocarle la corona al niño, éste no le tapara el rostro, descubrieron al bajar la imagen del altar que el niño había cambiado su posición. Este hecho maravilloso conmocionó al padre Montoro, quien comenzó a celebrar la imagen sirviéndose del milagro, "así en el púlpito como fuera de él", "para exortar a los indios" a venerarla. De esta forma, creció entre ellos no sólo el respeto por esta imagen, sino también la presunción de que gracias a ella comenzarían a ser "respetados por los demás indios y favorecidos por los españoles" (Calancha 1972 [1639]; Ramos Gavilán 1976 [1621]).

Unos años más tarde, en 1587 , se produjo el primer milagro colectivo que la Virgen realizó para favorecer directamente a los indígenas como grupo (si bien ya había realizado sobre ellos seis milagros - sanaciones- de manera individual). Cuando los miembros de la parcialidad Anansaya se dispusieron a sembrar sus tierras en nombre de ella (para de sus frutos poder comprar las cosas necesarias para su servicio), a pesar de la sequedad del tiempo se vieron favorecidos por una lluvia inesperada. Viendo esto los de Urinsaya, que aún seguían reticentes a encomendarse a esta imagen y no habían acudido a la sementera, sintieron envidia y quisieron imitarlos sembrando sus chacras. Sin embargo, no tuvieron la misma 
suerte que sus vecinos (según el autor, debido a su obstinación). Durante otra sequía de ese mismo año, luego de que los de Anansaya le hicieran a la Virgen una misa pidiéndole socorro, llovió copiosamente sobre sus tierras sin que cayera "una sola gota" sobre la otra parcialidad. Este hecho instó a los vecinos incrédulos a reconocer los milagros de la Virgen y a pedirle arrepentidos que les mandase agua a ellos también, luego de lo cual llovió sobre todas las chacras de Copacabana (Ramos Gavilán 1976 [1621]: 131).

El recorrido por estos primeros milagros nos lleva a las siguientes consideraciones. En principio, respecto del primer prodigio que funcionó como detonante del desarrollo del culto, vemos que hasta el momento en que la imagen lo realizó, hubo un rechazo inicial hacia ella de parte de la autoridad eclesiástica (el padre Montoro) y de los indígenas de la parcialidad Urinsaya, que no aceptaban una imagen de factura local. Sólo después de su primera manifestación milagrosa logró el reconocimiento de autoridades civiles, eclesiásticas e indígenas. Fue ese el impacto del prodigio en el convento de San Francisco: movilizar las iniciativas y acciones del corregidor y del cura de Copacabana, y del gobernador de los de Urinsaya, para que la imagen fuera llevada hasta la iglesia de ese pueblo. Asimismo, creemos que al haber precedido este milagro la constitución efectiva de la cofradía, pudo haber influido en la manera en que ésta se llevó a cabo. Posiblemente, de no haber sido por la intervención de las autoridades que motivó, la licencia del obispo no hubiera bastado para que la fundación se concretara con tanta aceptación.

Sin embargo, no obstante las decisivas implicancias de esta primera revelación de la Virgen, hemos visto que no bastó para la aprobación de la imagen entre los habitantes de Copacabana. Fue necesaria, como se desprende de los efectos que sobre los fieles tuvo el episodio de la cruz de bronce, una manifestación pública y contundente que los convenciera de sus capacidades milagrosas. Un hecho prodigioso que los mismos habitantes de Copacabana pudieran observar, a diferencia del ocurrido en La Paz en la privacidad de la celda de un religioso.

Un lugar especial merece el particular suceso de la autotransformación de la imagen de la Virgen, en tanto ha sido definido como el umbral entre los milagros "de conquista", históricos, construidos a posteriori, y como milagro en beneficio de los indios (Estenssoro 2003). Siendo esta imagen la obra de un indio neófito que modeló una forma imperfecta siguiendo el modelo de la Candelaria, dicho milagro - a simple vista impersonal-implicaba un reconocimiento de la Virgen a la capacidad indígena de producir sacralidad por encima de la negativa de las autoridades de la Iglesia colonial. Con esto, tanto ella como su hijo (por ser él quien se reclinó) se convertían en "abogados" de la plena incorporación de los indígenas al catolicismo, iniciándose una nueva era de milagros que se multiplicaron, a partir de 1583 , especialmente en beneficio de éstos (para desconfianza de muchas autoridades religiosas hacia las imágenes milagrosas que comenzarían a aparecer hacia principios del s. XVII) (Estenssoro 2003).

De esa manera, los siguientes seis milagros que la virgen realizó estuvieron dirigidos directamente a ellos, de manera individual primero, y luego a través de un suceso que los favoreció en términos colectivos. No obstante, respecto a éste último, hemos visto que en principio no fue un beneficio general hacia todos los naturales de Copacabana sino sólo para los de la parcialidad Anansaya, quienes creían en ella y la servían invocando su protección. Es aquí donde aparece el principal efecto de este prodigio de la lluvia: persuadir a los indígenas de Urinsaya, que aún permanecían incrédulos, sobre la sacralidad y poderes de la imagen.

Habiendo logrado, entonces, consolidarse y ser aceptada por la población de Copacabana y sus alrededores, dos años después, en 1589 , el culto comenzó a ser supervisado por los frailes agustinos.

\section{* La llegada de los agustinos: Multiplicación DE LOS MILAGROS Y EXTENSIÓN DEL CULTO (1589-1652)}

Durante los años previos a la llegada de los agustinos a Copacabana, cuando todavía la doctrina se hallaba en manos del padre Montoro, la imagen ya había comenzado a alcanzar una considerable trascendencia tanto a orillas del Titicaca como en lugares más alejados. Un ejemplo de esto es la divulgación en Copacabana de un acuerdo para trasladarla a la Catedral en la sede episco- 
pal de Chuquisaca (La Plata), ante lo cual los indígenas y el padre Montoro intentaron oponerse ocultándola en la casa del mayordomo de la cofradía (Calancha 1972 [1639]; Ramos Gavilán 1976 [1621]). Asimismo, es ilustrativo el registro en una fecha tan temprana (1958), de un hecho prodigioso con esta imagen en la ciudad de Salta (Ramos Gavilán 1976 [1621]). De esta manera, la creciente cantidad de devotos que llegaban a Copacabana, llevó a que las autoridades consideraran apropiado remover al padre Montoro de su cargo para que una orden religiosa se hiciera cargo de la doctrina (Calancha 1972 [1639]; Ramos Gavilán 1976 [1621] Salles-Reese 1997).

A partir de ese momento, entonces, nos encontraremos frente a milagros que favorecieron la difusión y extensión del culto, en su gran mayoría referentes a casos similares de personas -tanto de Copacabana y pueblos aledaños como de lugares más alejados- que fueron sanados/salvados por ella después de invocarla o venerarla. ${ }^{18}$ Aunque mayormente eran indios, también ayudaba a negros, mestizos, mulatos, españoles y criollos de distinta condición social que, en agradecimiento, solían ir a su santuario y rezarle novenas (Salles-Reese 1997; Van den Berg 2002).

Haciendo entonces un seguimiento de los numerosos prodigios que los cronistas nos presentan para los años posteriores a 1589 (según Ramos Gavilán 138, de los cuales Calancha reproduce 132 agregando otros 76; ver Van Den Berg 2002), nos detendremos en ciertas situaciones particulares vinculadas a milagros colectivos, en principio, y luego a milagros individuales.

\section{Milagros colectivos}

Es en este tipo de prodigios donde suele manifestarse una devoción a la virgen en términos más comunitarios y una participación significativa de autoridades civiles y religiosas. Especialmente cuando son obrados durante

\footnotetext{
${ }^{18}$ En su análisis sobre los milagros de esta imagen Van Den Berg (2002) incluye una descripción de la progresiva expansión de la devoción hacia distintos lugares cada vez más alejados del santuario, subrayando la significativa mayor cantidad de milagros correspondientes a los primeros años de la presencia agustina en Copacabana (1589-1592), frente al período posterior (1593-1653) con sólo algunos prodigios por año.
}

momentos críticos para la sociedad en su conjunto, como una sequía en Chucuito en 1592 (Calancha 1972 [1639]: 363; Ramos Gavilán 1976 [1621]: 178), una densa oscuridad en Copacabana producto de una tormenta de ceniza en Arequipa en 1600 (Calancha 1972 [1639]: 415; Ramos Gavilán 1976 [1621]: 191), una peste general en Perú en 1619 (Calancha 1972 [1639]: 515; Ramos Gavilán 1976 [1621]: 225), y una helada en Copacabana en 1633 (Calancha 1972 [1639]: 565). En los primeros tres casos, el accionar de los pueblos afectados fue acudir a los religiosos del convento para poder sacar la imagen en procesión a fin de que ésta pudiera ayudarlos. Durante el cierre de Copacabana en 1600, se muestra además, que a la procesión realizada acudieron también "sacerdotes de las provincias de Chucuito, Cepita y Yunguyo, y algunos religiosos, el Gobernador y mucha gente española" (Ramos Gavilán 1976 [1621]: 191).

Otro milagro colectivo significativo es aquél que ocurrió en 1618 para la celebración de Corpus Christi, el último de los relatados por estos cronistas- a través del cual la Virgen benefició colectivamente a los indígenas manifestándoles su beneplácito (en los prodigios que siguen, lo hizo a través de milagros individuales). Cuando todos los curaca e indios principales fueron de común acuerdo a tratar con los religiosos del convento para pedirles les permitieran asentarse como esclavos del "Santísimo Sacramento" y salir alumbrando al "Señor" al igual que los españoles, lograron su cometido gracias a que al día siguiente amanecieron las lámparas del Santísimo y de la Virgen vertiendo aceite "como aprobando el Señor con este milagro lo que los indios trataban" (Calancha 1972 [1639]: 511; Ramos Gavilán 1976 [1621]: 225).

\section{Milagros individuales}

Con respecto a los milagros individuales (los más frecuentes), nos interesa exponer cómo en la narración de algunos se indica quiénes dan cuenta de ellos, colaborando en su difusión, y se señala dónde y quién recibe las informaciones correspondientes. ${ }^{19}$ Mas allá del propio testimonio de quienes resultan beneficiados -que gene-

\footnotetext{
${ }^{19}$ Más del 80\% del total de milagros son individuales. Muchos suceden durante la realización de una misa, frente a gran cantidad de personas que pueden atestiguarlo y difundirlo (Ramos Gavilán $1976[1621]: 158)$.
} 


\begin{tabular}{|c|l|l|l|}
\hline Año & \multicolumn{1}{|c|}{ Beneficiado } & \multicolumn{1}{|c|}{ Milagro } & \multicolumn{1}{c|}{ Informantes, testigos } \\
\hline 1587 & Un indio uro & Sanado de su tullidez & $\begin{array}{l}\text { Narrado por el Licenciado Diego de Flores en uno de sus libros, donde } \\
\text { enfatiza mucho su carácter de testigo presencial del milagro. }\end{array}$ \\
\hline Abril, 1589 & Una india de Yunguyo & Salvada de la muerte & Cura de Yunguyo, el Licenciado Villalta. \\
\hline 1599 & Un español & Sanado de una pierna & Corregidor de La Paz, Peralta Cabeza de Vaca. \\
\hline 1614 & $\begin{array}{l}\text { El padre Angulo, } \\
\text { Ge San Francisco de } \\
\text { Cochabamba }\end{array}$ & Sanado de una dolencia física \\
1617 & $\begin{array}{l}\text { Un hombre del reino de } \\
\text { Chile }\end{array}$ & $\begin{array}{l}\text { Recuperó la vista al invocarla } \\
\text { purante una misa en la iglesia } \\
\text { días del escaso aceite que quedaba para la lámpara de la imagen de } \\
\text { Copacabana que había en el altar mayor de la iglesia. }\end{array}$ \\
\hline 1618 & $\begin{array}{l}\text { Un religioso de la } \\
\text { Compañía de Jesús }\end{array}$ & $\begin{array}{l}\text { Las informaciones del caso fueron hechas por el vicario, y nuevamente, } \\
\text { por orden del padre Prior, cuando el hombre llegó a Copacabana -en } \\
\text { tanto se hallaban allí muchas personas que lo habían conocido ciego y } \\
\text { que estuvieron presentes durante el milagro. }\end{array}$ \\
\hline 1630 & $\begin{array}{l}\text { Un esclavo negro de una } \\
\text { estancia de Chucuito } \\
\text { algodones tocados por la } \\
\text { imagen }\end{array}$ & $\begin{array}{l}\text { Recuperó su vista y fue } \\
\text { socorrido dos veces por unos } \\
\text { indios }\end{array}$ & $\begin{array}{l}\text { El mismo religioso se lo refirió a Ramos Gavilán, en ese momento } \\
\text { Vicario Prior del convento, escribiéndole desde Juli. }\end{array}$ \\
\hline
\end{tabular}

Tabla 1. Milagros de cuyas informaciones y registros se deja constancia (Calancha 1972 [1639]; Ramos Gavilán 1976 [1621]).

ralmente opera de manera muy persuasiva sobre los presentes-, en varias oportunidades los autores explicitan quiénes refieren las informaciones sobre los milagros obrados por la Virgen a nivel individual (Tabla 1).

En otros casos, los milagros quedaron pintados en imágenes expuestas en los conventos de San Agustín de Copacabana y Cusco (Calancha 1972 [1639]:378; Ramos Gavilán 1976 [1621]: 179, 190). De alguna manera, creemos que este afán de los religiosos por registrar y proclamar este tipo de milagros puede vincularse precisamente a su carácter individual, en tanto acontecimiento que opera fundamentalmente a nivel personal y cuyo impacto sobre quien los recibe solo puede hacerse extensible a los demás en tanto sea divulgado y transmitido.

Asimismo, es interesante observar el accionar verificador de los religiosos luego de darse a conocer un suceso milagroso. Por ejemplo, cuando un indio natural de Ilabe dio cuenta al pueblo y a los frailes de haber sido sanado de su tullidez luego de pasar la noche junto a la imagen: “...hicieron los Religiosos examen riguroso de aquel suceso (que como nuestra fe ha de menester valerse ya de milagros, es bien sea apretado el escrutinio), hallaron en este hecho que concurrían todas las razones de milagro" (Ramos Gavilán 1976 [1621]: 147).

Otro milagro individual - en el cual la virgen se le aparece a una india tullida para evitar que se suicide con veneno- llevó por un lado a que los religiosos lo publicaran con repiques de campanas para exhortar a las personas a que acudieran a ella, y al padre Prior del convento de Copacabana, fray Pedro de Mora, a hacer las averiguaciones sobre lo referido. Luego de sucederse otros prodigios con esta misma mujer, fueron referidos al autor por el Prior en calidad de testigo presencial e informados nuevamente ante la llegada del Padre Provincial fray Diego Pérez (Ramos Gavilán 1976 [1621]: 203, 204).

Quien incluye una detallada descripción del tipo de documentación producida sobre los milagros de esta imagen es Van Den Berg (2002), distinguiendo por un lado las actas o informaciones oficiales, y por el otro las 
cartas enviadas a la Virgen por los devotos. En base a estas informaciones acumuladas en el archivo del santuario (Calancha 1972 [1639]: 590; Ramos Gavilán 1976 [1621]: 192, 138), sumada a los testimonios recogidos, los autores desarrollaron sus obras, explicitando en muchos casos sus esfuerzos por controlar y comprobar los datos obtenidos a fin de registrar solo los milagros más fidedignos -en definitiva aquellos que concordaran con su definición teológica, por encima de otras posibles lecturas de los devotos-. Esto expresa claramente la influencia de las disposiciones tridentinas que prohibían la divulgación de milagros no verificados correctamente y exigían una cuidadosa certificación, dictándose normas para la declaración de milagros y apariciones con informes notariales y con testimonios de testigos y beneficiarios (Christian 1991).

\section{Nuestra Señora de Copacabana en otras áreas del virreinato del Perú}

Como pudimos observar a través de los prodigios referidos, las maravillas obradas por esta virgen lograron trascender y extenderse a lo largo de las distintas provincias y ciudades del virreinato. En principio, para ilustrar la manera en que los milagros se difundían de un lugar a otro dentro de la geografía colonial, podemos citar uno de los relatos de Ramos Gavilán donde señala que:

“...los años pasados habían acudido a este Santuario unos soldados del Reino de Chile y contaron a los Religiosos como en la guerra que tienen los Indios con los Cristianos en aquel Reino, habian cogido los enemigos a uno de los Indios Cristianos [...] el cual por haber oído decir muchas veces a los españoles los milagros que la Virgen de Copacabana hacía se encomendó a la bendita Imagen $[. .$.$] y acudiendo los españoles a favor del indio$ empicado le hallaron en tierra sin lesión alguna (Ramos Gavilán 1976 [1621]: 183; subrayado es nuestro).

Las crónicas también refieren a personas de otros reinos (como España, México y Nueva Granada) que invocaron a la Virgen en situaciones peligrosas por haber oído de sus milagros, y que siendo salvados por ella deciden acudir a su santuario o enviar valiosas ofrendas en agradecimiento (Calancha 1972 [1639]; Ramos Gavilán 1976 [1621]). Pero más allá de esta difusión de los milagros entre las personas que circulaban en este territorio, es interesante atender cómo se organizó y consolidó el culto a esta imagen en otras ciudades, a fin de poder analizar con más elementos el lugar del milagro en el proceso de construcción del culto y observar las relaciones y tensiones que se fueron generando al interior de la sociedad colonial en relación con dicho proceso. Para ello, consideraremos la descripción que hace Ramos (2005) sobre la trayectoria de la cofradía de indios organizada en torno a esta virgen en Lima.

Cuando una disputa por la creación del barrio limeño de Cercado enfrentaba a jesuitas, virrey y arzobispo, una imagen de la Virgen de Copacabana que había sido colocada en una modesta capilla del barrio San Lázaro en Lima, se manifestó de manera milagrosa ante diversos testigos. Poco después, el arzobispo movilizó la organización de una cofradía de indios, posteriormente trasladada junto con la imagen a la Iglesia Mayor de Lima. Como la protección del prelado fue crucial para que el culto fuese tolerado por el cabildo de la catedral, luego de fallecer aquél, en 1606, se tensionaron las relaciones entre los miembros de la cofradía y los sectores más altos de la sociedad. Se removió la capilla donde estaba la imagen y el cabildo no autorizó la concesión de un nuevo espacio en la Iglesia Mayor para las actividades de la cofradía. Con esto, el clero estaba marginando a un grupo organizado de indios limeños y manifestando su rechazo a un culto que identificaba a la población indígena como colectividad (Ramos 2005). Asimismo, las disputas que nos describe la autora entre los cófrades y mayordomos indígenas con los sucesivos capellanes, muestran de qué manera eran percibidos contradictoriamente estos nuevos cristianos: por un lado como los indios "buenos" cuyo ejemplo debían seguir los demás, y por el otro, como incapaces de comprender el significado de la devoción que los congregaba. Sin embargo, más allá de estas tensiones interétnicas y a pesar de la voluntad del clero de asociar al culto con el perfil indígena de la cofradía formada en torno a él, la devoción a la Virgen de Copacabana exhibía un "carácter potencialmente integrador" (Ramos 2005: 168). Aquel milagro inicial en la capilla de San Lázaro había movilizado el favor, la devoción y la participación de los sectores más privilegiados de la sociedad, pudiendo encontrarse representaciones de la Virgen para uso personal en manos incluso de criollos y españoles. Por el impacto que produjo entre los fieles, que según los autos del proceso de verificación del suceso ya eran de distinta condición socioétnica (mulatos, 
españoles, negros e indios) podemos afirmar que ese milagro fue el factor que más contribuyó a que el culto se fortaleciera entre distintos sectores de la sociedad (Ramos 2005: 165). La conclusión de la autora es que en una sociedad llena de divisiones y conflictos como fue la del virreinato durante el s. XVII, que pudieran cristalizar las convenciones sobre la auténtica representación de una devoción andina, es un indicio del éxito alcanzado por la Virgen de Copacabana como intermediaria cultural. Su capacidad para convocar la fidelidad de personas de disímiles procedencias y su gran valor comunicativo entre distintas esferas culturales, políticas y étnicas permite atribuirle ese rol.

\section{* Reflexiones en torno a la construcción SOCIAL DEL CULTO: INDIOS CRISTIANIZADOS Y AFÁN EVANGELIZADOR}

¿Desde qué lugar, entonces, se construyó el culto a la Virgen de Copacabana? En una primera mirada a los datos presentados, puede advertirse que fueron indígenas quienes lo promovieron, animados por el anhelo de constituir una cofradía y de servir a una imagen que los representara y protegiera en sus dificultades. Pero si bien este protagonismo indígena fue considerable, con importantes implicancias que a continuación describiremos, hubo otros actores que intervinieron decisivamente en el proceso de surgimiento y consolidación del culto.

\section{El papel de los indios: Continuidades en torno a una nueva devoción}

El proceso que implicó encontrar un lugar para la imagen fue creando un vínculo especial entre el personaje celestial y la comunidad, vínculo que se reafirma cuanto mayores han sido los errores y las dudas del pueblo (Christian 1991: 58). Los obstáculos que debieron atravesar el gobernador de Anansaya y el escultor de la imagen para poder lograr la autorización del obispo, son al mismo tiempo indicadores y afianzadores del interés y la devoción que los movilizaba. Siguiendo a Salles-Reese (1997), en el origen de esta virgen puede percibirse el deseo y necesidad de los indígenas de participar activamente en la nueva religión que se les imponía y que empezaban a asimilar, para apropiársela de alguna manera a pesar de lo ajeno de sus dogmas y rituales.
En esta apropiación y progresiva internalización de la simbología que la imagen expresaba, operaron significativamente las características de las divinidades e imágenes sagradas prehispánicas (Salles-Reese 1997; López 1998). Cuando la imagen de la Virgen comenzó a desplazar simbólicamente a la Peña Sagrada del Tawantinsuyo, un inmenso escenario de culto al Sol, a la Luna, a la Pachamama y a otras hierofanías tradicionales, dio lugar a una compleja liturgia cristiana (Báscones 1998). Al igual que en Europa, María en tanto madre de Dios fue una imagen apropiada para heredar la tradición de las diosas-madres vinculadas al paisaje rural, por ser más fácil de asimilar a la Madre Tierra, a la Luna, y a las divinidades asociadas con la fertilidad. Por ello, los santuarios marianos fueron ganando preeminencia sobre las imágenes y símbolos locales en tanto dispensadores de la ayuda divina (Christian 1991: 36 , 62). Sin embargo, en el Área Andina es notable la persistencia de los cultos tradicionales a los espíritus de la tierra y de los cerros, que han ido articulándose con las creencias y ritos cristianos. De esta forma, la presencia de la Virgen de Copacabana y la difusión de sus milagros en la población local, ha proporcionado lazos de continuidad a nivel cultural y religioso, suavizando la transición entre el pasado andino y el nuevo orden cristiano, y permitiendo la permanencia -aunque resignificada- de la sacralidad del lago Titicaca (SallesReese 1997; Báscones 1998). Así, por ejemplo, podrían identificarse en torno a la figura de la virgen elementos y sentidos asociables a la huaca de Copacabana. Es decir, más allá de la propia etimología del denominador aymara-quechua "Copacabana" "observar el lago, mirador de la piedra preciosa o mirador del azul precioso" (Luján 2002: 196), están presentes sus vinculaciones con el agua (en relación con sus milagros pluviales y con su cercanía al lago) y con el color azul (en las características de su manto). No es un hecho menor, en este sentido, que en la denominación de la Virgen se haya conservado esta antigua expresión ("Copacabana"), con todas las connotaciones que la rodeaban, como tampoco que ella haya opacado a la advocación hispana que le dio origen (la Virgen de la Candelaria).

Asimismo, como vimos en la introducción, la movilización de devotos de zonas alejadas hacia Copacabana era algo que ya se daba desde la época incaica con las peregrinaciones a las islas sagradas del Sol y de la Luna, cuyos 
templos atraían romerías incluso de sitios tan distantes como Chile y Ecuador (Calancha 1972 [1639]: 121; Báscones 1998). De manera que ya existía no sólo una cierta "infraestructura" para este tipo de congregaciones de peregrinos en torno al área del Titicaca (hospederías, depósitos, graneros, personal de servicio y mantenimiento, entre otros), sino también una importante tradición de romerías que debió haber influido significativamente en la fisonomía del culto a la Virgen. Más allá de las distancias y diferencias entre esos cultos prehispánicos y esta nueva devoción cristiana, Copacabana seguía actuando como centro de irradiación religiosa.

En un nivel distinto, dichos lazos de continuidad se dieron también en términos sociopolíticos, en la posibilidad de una persistencia de ciertas estructuras andinas. Nos referimos a las relaciones de poder entre las parcialidades Anansaya y Urinsaya, ya reestructuradas por el sistema incaico. Recordemos que el escultor Tito Yupanqui era descendiente de la élite incaica y pertenecía a la parcialidad Anansaya; y si durante el régimen imperial era esta mitad la que prevalecía, su preeminencia sobre Urinsaya podía reproducirse en el período Colonial -aunque fuera sólo en términos simbólicosgracias a la entronización de una virgen que ellos mismos habían elegido como patrona (Salles-Reese 1997). Al mismo tiempo, teniendo en cuenta esa ascendencia incaica del escultor, y el carácter de la participación de su padre (Paullu Inka) durante las expediciones de conquista al Collao, con su posición más negociadora y su acercamiento a la religión cristiana, es posible colegir que las resonancias de su rol se hacían patentes en la figura de uno de sus hijos. De esta forma, la milagrosa imagen de la Virgen de Copacabana creada por Tito Yupanqui ha sido entendida también como una suerte de reivindicación de su padre Paullu y como vehículo para la perpetuación de la influencia religiosa de la panaca de Viracocha hasta tiempos coloniales (Bouysse-Cassagne 2004; Medinacelli 2007).

\section{Autoridades coloniales y órdenes religiosas}

Por otra parte, si el surgimiento del culto fue a partir de iniciativas de la población indígena, fueron las autoridades locales, corregidor y cura, quienes primero se involucraron después que la imagen manifestó su primer milagro, para alentar y asegurar el culto pero también para encauzarlo. Es notable en este punto el repentino cambio de actitud de las autoridades, que pudo haber sido motivado por la necesidad de apropiarse de una imagen de factura nativa que comenzaba a manifestar su poder. Podemos preguntarnos también por qué no pudieron fundarse dos cofradías distintas, una para cada mitad, respetándose el principio de oposición complementaria que caracterizaba la organización sociopolítica y cósmica de las poblaciones andinas. Esa necesidad de acordar entre ambas parcialidades una única imagen de culto, nos puede estar mostrando cómo se impuso en este caso la lógica europea por sobre la dualidad andina.

Debido a estas decisiones de los funcionarios locales, fueron entrando en escena autoridades coloniales más altas. Por iniciativa del corregidor, que buscaba canalizar la devoción a la Virgen a través de su delegación a alguna orden regular, la Real Audiencia de Charcas se involucró en la trayectoria del culto para encomendárselo a los frailes agustinos. Al momento de decidir a cargo de quién seguiría la doctrina, también el virrey Conde del Villar y la sede vacante de Chuquisaca tomaron parte en el asunto objetando que la Audiencia se la quitara al cura Montoro, seguramente por las mismas tensiones con el clero regular que unos años atrás habían motivado la remoción de los dominicos. Finalmente, y en función de esta controversia, el destino del culto llegó a manos del mismo rey, quien a través de una cédula de 1588 apoyó la disposición de la Audiencia ordenando entregar la imagen a la orden de San Agustín.

Indudablemente, los religiosos de esta orden fueron actores centrales en el desarrollo del culto a la Virgen de Copacabana: se apropiaron de él eficazmente y cumplieron un papel protagónico en su difusión en el Alto Perú (Ramos 2005). Como vimos, aunque la designación de los agustinos fue motivada por las dimensiones que ya venía adquiriendo la devoción, luego de su llegada a Copacabana la convocatoria de esta imagen fue creciendo progresivamente, llegando a ser reconocida y venerada por representantes de distintos sectores de la sociedad colonial.

En este sentido, creemos que el papel de la Virgen como intermediaria cultural entre distintos sectores (Ramos 2005), en una sociedad con marcadas diferencias y desigualdades internas, está íntimamente ligado a sus capacidades milagrosas, más precisamente al milagro en 
tanto signo de Dios y, fundamentalmente, en tanto símbolo. Al ser ante todo signos de la voluntad divina, los milagros posibilitaron la creación de un canal de comunicación entre los fieles en un plano simbólico-religioso. Incluso, podían estimular la experimentación de ciertas relaciones (p.e., entre los miembros de una cofradía) como providenciales y primordiales, afirmando sentidos de pertenencia a una determinada comunidad de devotos (Costilla 2007). ${ }^{20}$

El compartir las mismas devociones puede ayudar a dar cohesión a las sociedades frente a la acción disgregadora de las desigualdades socioeconómicas y diferencias culturales (Christian 1991: 181). Para el caso de Copacabana, recordemos que al momento en que ingresaron las primeras expediciones de conquista, el pueblo estaba habitado por mitimaes incaicos de más de 40 naciones distintas; y ya para la época de consolidación del culto, el panorama que se percibía era el de una sociedad multiétnica con una población indígena muy heterogénea, para la cual debe haber sido central el papel de un culto que los congregara. El poder simbólico de la imagen milagrosa podía operar en esas diferencias tan radicales al interior de la sociedad colonial, y de la propia sociedad indígena, atenuando en una dimensión religiosa las contradicciones entre los distintos sectores. Es justamente esta potencialidad polisémica del milagro la que lo habilita para poder ser esgrimido desde distintos actores para diversos fines e intereses.

\section{^ Los usos del milagro: “EN tierras nuevas SIEMPRE USÓ DIOS DE ELLOS" ${ }^{21}$}

Llegamos entonces al último punto que nos interesa abordar: cuáles son los usos y apropiaciones de lo religioso en general, y del milagro en particular, que las fuentes analizadas nos permiten vislumbrar para el proceso de consolidación del culto. Como bien sostiene Ramos (2005), la devoción a Nuestra Señora de Copacabana en el virreinato del Perú simbolizaba la conversión del indígena, al tiempo que su trayectoria se consolidó a través de la participación de distintos sectores

\footnotetext{
${ }^{20}$ Para una definición del concepto de primordialización, ver Brow (1990).

${ }^{21}$ Ramos Gavilán 1976 [1621]: 195.
}

de la sociedad. Es esperable entonces, que esa devoción haya sido esgrimida desde cada uno de ellos con sentidos e intereses particulares.

Por un lado, esta conversión del indígena se vincula directamente con un objetivo central de la Iglesia colonial y con la eficaz función del milagro en tanto signo de Dios. Como vimos, el culto fue convenientemente apropiado por los frailes agustinos para su desarrollo, principalmente en esta dirección. De ahí que el uso del milagro más presente en los testimonios considerados, sea en relación con este fin evangelizador y, en un sentido similar, para atraer nuevos devotos y para motivar a sus fieles a seguir sirviéndola (Ramos Gavilán 1976 [1621]: 182, 183 , $189,196,215$, entre otros). ${ }^{22}$ A lo largo de sus obras, los cronistas agustinos subrayan en numerosas ocasiones esta suerte de "triunfo" de la Virgen de Copacabana por sobre la idolatría y los antiguos ritos "demoníacos" de la población nativa. Por ejemplo, en relación con el prodigio de la duración extraordinaria de una botijuela de aceite de la Virgen, Ramos Gavilán indica:

“...admirados los Indios de ver semejante cosa, dejábanse ya de ritos y ceremonias y pública y secretamente las condenaban, procurando en todo lo que podian imitar a los españoles en la devoción, y encomendarse a Dios y a su Santísima Madre, llamándola en sus necesidades, y trabajos, y viendo que de tierras tan lejanas acudían los cristianos sólo a visitar la Imagen, guiados de su fama, [...] acudían ellos con mayores veras a servirla" (1976 [1621]: 138-139).

En relación con prácticas paliativas tradicionales de las sociedades indígenas, Calancha señalaba que:

“...en Copacavana ha desterrado la Virgen estas hechicerías, que como los indios las hacen para aplacar al aire y al cielo, como ellos dicen, ven sus indios que puede más una lágrima que le lloran y un ruego que le hacen que todos los embelecos de los hechiceros ni la fuerza de las supersticiones" (Calancha 1972 [1639]: 566).

Considerando que gran parte de los prodigios individuales de la Virgen tuvieron a indígenas como protagonistas,

\footnotetext{
22“De esto sirven los milagros que en tierras nuevas siempre usó Dios de ellos para acreditar su doctrina y ley Evangélica; y para que el pueblo crea en él, y acuda a él, fortaleciéndole en la fe"" (Ramos Gavilán 1976 [1621]: 195).
} 
se entiende que el impacto entre ellos fuera más fuerte, porque les "hablaban" más claramente que los abstractos preceptos eclesiásticos. Y es por eso también que fueron estratégicamente usados por los religiosos en los sermones y reuniones donde aquellos asistían (Salles-Reese 1997). Dada la forma en que operan los milagros individuales, a nivel más personal en términos de conversión o de reafirmación de la fe, proclamarlos entre los demás indígenas podía estimular un eficaz efecto multiplicador.

Asimismo, los primeros indicios de diferentes usos de un prodigio que podían hacer distintos actores de la sociedad colonial, los encontramos ya en las consecuencias de aquel milagro impersonal inicial de la autotransformación de la imagen de la Virgen. Por un lado, el cura local lo comenzó a utilizar para exhortar a los indios recurriendo a su sentido más general en tanto "signo de Dios". Pero aquellos, a su vez, también resultaban beneficiados (según Ramos Gavilán 1976 [1621]: 129) con la posibilidad de obtener el respeto de otros indígenas y el favor de los españoles; lo que nos muestra una dimensión distinta del milagro, no ya en tanto signo sino como símbolo del beneplácito de la Virgen hacia esta especial representación suya. Lo mismo puede decirse del ya citado prodigio del aceite de la lámpara del Santísimo Sacramento gracias al cual los curaca y principales lograron incorporarse a la procesión del Corpus Christi. No obstante ser en principio un milagro impersonal, lo hemos presentado como colectivo en tanto habría sido entendido -siguiendo la interpretación de los cronistas- como símbolo de la aprobación de la Virgen y su hijo hacia la voluntad de participación de los indígenas en tan importante festividad cristiana (Calancha 1972 [1639]: 511; Ramos Gavilán 1976 [1621]: 225). Años más tarde, el escultor de la Virgen Tito Yupanqui, hallándose por su edad imposibilitado de seguir trabajando, alegó su papel de creador de esa imagen que de tanto provecho había sido para el "acrecentamiento de la fe" y la "extirpación de la idolatría" para solicitarle ayuda económica al padre provincial de los agustinos (Ramos Gavilán 1976 [1621]: 204). Volveremos sobre estos temas.

Otra de las maneras en que resultaba esgrimida esta imagen desde la población nativa, es en relación con los momentos de catástrofes. Ya desde los primeros votos a la Virgen por parte de la parcialidad Anansaya, encontramos esta especial vinculación entre desastres naturales e invocaciones colectivas a imágenes religiosas que es propia de la "religiosidad local", 23 ya sea en la Europa moderna como en América prehispánica. Así, al igual que en España en el s.XVI, una manera muy común de paliar las desgracias en las sociedades andinas coloniales fueron las procesiones rogativas, sumado esto a las creencias tradicionales en la intervención activa de los seres sagrados en los asuntos humanos y mundanos, lo cual implica la necesidad de aplacar sus iras (Christian 1991).

En relación con otros actores, por ejemplo autoridades civiles, es posible identificar ciertos usos más "profanos" de esta imagen y sus milagros. En uno de los últimos prodigios que describe Calancha, del año 1651, se observa un recurso a esta imagen de parte de ciertos funcionarios coloniales durante la celebración del Día de la Purificación en Copacabana. Según nos explica el autor, cuando el corregidor de La Paz y su teniente general convencieron a los indios de Copacabana que solicitasen al padre Prior sacar la imagen en procesión para que Dios les diese agua, sus verdaderas intenciones eran "hacer su negocio" a partir de la mayor afluencia de gente que habría para "juegos, coimas, distraimientos y otras cosas de escándalo" que solían llevarse a cabo durante esas fiestas paralelamente a los actos religiosos (Calancha 1972 [1639]: 622). Este es un pequeño ejemplo de cómo se tensionan los intereses de autoridades civiles y religiosas en relación con la imagen: mientras que el corregidor y su teniente aducían ser ésta de los indios y demandaban al Prior que se hiciera la voluntad de ellos de sacarla en procesión, el religioso les advertía, alegando conocer sus intereses "reales", que la Virgen se defendería de ellos "con prodigios y milagros". De manera que un mismo milagro, en este caso la lluvia en tiempos de sequía, podía significar para unos la posibilidad previa de un mayor concurso de gente y para otros el fin de las demandas malintencionadas de los primeros.

Retomando ahora el tema de los usos de esta imagen por parte de la población indígena, ¿qué otras dimen-

23 Concepto acuñado por Christian (1991) para referirse a la religiosidad historizada y localizada en un determinado pueblo o ciudad y practicada por una sociedad particular. Lo propone como noción alternativa a la expresión "religiosidad popular", para evitar las connotaciones unilaterales que rodean al término (rural, tradicional, primitivo, proletario, entre otros). 
siones se divisan tras la idea de la Virgen en tanto símbolo de la conversión de los indios? Teniendo en cuenta que muchos de ellos ya habían sido cristianizados -principalmente los descendientes de la élite incaica-, el milagro, más que actuar en un sentido evangelizador, podía para ellos volverse un recurso estratégico para mantener sus posiciones y privilegios. ¿Por qué los de Anansaya no aceptaron a San Sebastián como patrono, tal como proponían los de la otra mitad, y ansiaban que la cofradía fuera de la Virgen? Probablemente existía una cuestión de prestigio que motivaba esa elección (López 1998: 132); o un intento por conservar prerrogativas en un contexto colonial donde el orden social, con su creciente complejidad, relegaba y explotaba cada vez más a la sociedad indígena sin mayores reconocimientos de distinciones sociales. Por su parte, para los antiguos habitantes locales -los indios yunguyos-, cuyas deidades habían sido relegadas por la religión oficial impuesta por los incas, la Virgen de Copacabana reavivaba con su denominación las connotaciones de una antigua huaca local desplazada por el culto solar. Lamentablemente, las fuentes consultadas no nos proporcionan mayores datos para la identificación del uso del milagro en estos sentidos más particulares ni en relación a las rivalidades más generales entre las mitades Anan y Urin. Pero sería interesante preguntarnos de qué manera éstas continuaron expresándose una vez superados los desacuerdos iniciales en torno a la elección de la imagen.

En definitiva, y más allá de sus diferencias y rivalidades internas, creemos que los milagros de esta imagen le permitían a la población indígena en general legitimar su lugar dentro de la sociedad colonial en tanto nuevos cristianos. Recordemos lo analizado para la autotransformación de la imagen de la Virgen, para el prodigio con la lámpara del Santísimo Sacramento y para la solicitud de Tito Yupanqui al provincial de los agustinos. Al mismo tiempo, esos milagros fueron los que favorecieron la reconsagración de un lugar central de la geografía religiosa prehispánica, pudiendo leerse la referida sustitución -tan destacada por los cronistas- de las creencias y prácticas paganas por el culto a la Virgen, como una estrategia de los indios para preservar su espacio sagrado en el rango que acostumbraban reconocerlo (López 1998: 137). De esta manera, proponemos que los indígenas podían recurrir al milagro y a esta particular imagen cristiana como eficaces herramientas simbólicas para la obtención de reconocimiento, para legitimar su lugar como cristianos y para garantizar el acceso a ciertos espacios y beneficios.

\section{* Consideraciones finales iel milagro A FAVOR DE LOS INDIOS?}

Para concluir, referiremos una interesante reflexión que hace Calancha (1972 [1639]: 214-215) acerca de porqué se produjo el milagro en ese momento histórico particular. Conjeturando porqué la Virgen lo habría elegido, indica tres posibles razones: 1) porque quería que los indios "conociesen que las imágenes de sus manos las honraba con hacerlas miraculosas, y no las que hacían los españoles"; 2) porque "no quiso entrar a hacer maravillas en Copacabana antes que aquel pueblo y comarca se empezase a convertir, sino cuando ya había algunos convertidos"; 3 ) porque consideró importante "aguardar a que se acabasen las guerras, y gozase el Perú la quietud de la paz". Era verdaderamente un momento propicio para el desarrollo de un culto que pudiera calar hondo en esa población recientemente conquistada y cristianizada. Y por supuesto que también lo era el lugar. Pero hemos visto que al analizar cómo operó el milagro en la sociedad donde este culto se desarrolló y consolidó, otras dimensiones se hicieron presentes.

Es evidente, siguiendo el razonamiento de Calancha, que colaboró en la incorporación de la simbología cristiana por parte de la población local; apropiación que habilitó formulaciones y prácticas sincréticas que articulaban sintéticamente elementos del catolicismo con creencias y ritos de sus religiones tradicionales (Marzal 1999). En este sentido fue propicio que el culto se construyera desde la iniciativa de fieles que pertenecían a la población colonizada, a partir de una imagen elaborada por un indio neófito sin mayores recursos para hacer valer su obra. Es por eso que en el proceso de progresiva aceptación fue decisivo el papel del milagro, como manifestación que persuadía eficazmente a los incrédulos y que simbolizaba el aval divino hacia una peculiar imagen de factura local y hacia la capacidad nativa de producir sacralidad. Aunque, como indica Ramos (2005), el proceso no haya estado exento de tensiones ligadas al rechazo hacia el fiel indígena como "buen cristiano". 
Pero también es cierto que en la sociedad donde se originó el culto, el milagro actuó de manera favorable a la reacomodación de las relaciones de poder y de los vínculos con lo sagrado. Un nuevo santuario cristiano, con sus simbolismos asociados y sus cuantiosos peregrinos, ocupaba el lugar de otros anteriores; y nuevos elementos se hicieron presentes para la recuperación de antiguos fueros y privilegios, principalmente para los miembros de la élite indígena y la descendencia de los viejos mitimaes incaicos. Como en el caso de la cruz de Carabuco, estas sustituciones simbólicas favorecieron a varios sectores de la sociedad, fueron un lugar de encuentro para los intereses de distintos actores que buscaban imponer y preservar desde diferentes lugares: autoridades civiles y eclesiásticas, religiosos, indios cristianizados, curaca y autoridades étnicas. De esta manera, es posible afirmar que, en este caso, más que en beneficio de algún sector en especial, el milagro operó a favor de la sociedad colonial, incluso a favor del orden colonial, con sus cada vez más acentuadas tensiones y contradicciones, y en el particular escenario que dejó la reorganización toledana. Colaboró, en cierta medida, en el necesario proceso de mutua adaptación entre las estructuras tradicionales y el nuevo marco social e institucional.

Aunque las fuentes aquí examinadas no nos permitieron avanzar en una más clara identificación de usos estratégicos del milagro, el análisis de los prodigios presentados por los cronistas agustinos nos ha mostrado de qué manera podían diferentes actores sentirse beneficiados por esa imagen y recurrir a ella en relación a sus intereses, ya fueran personales o colectivos. En qué medida ese recurso a la Virgen y a sus milagros se vincula con las características de los favores otorgados por ella, es algo que no podríamos responder cabalmente a partir de este único caso. ${ }^{24}$ Sería necesario un análisis comparativo con otros cultos, para evaluar asimismo posibles correspondencias respecto a la manera en que operan en la dinámica social cada uno de los tipos de milagros. ¿Son siempre los individuales los que colaboran en la difusión y extensión de un culto, los colectivos aquellos

\footnotetext{
${ }^{24}$ Teniendo en cuenta además que los usos del milagro pueden producirse en torno al propio carácter milagroso de la imagen y no en relación a un suceso prodigioso concreto, en cuyo caso sí puede influir -o no-el tipo de evento del que se trate y la interpretación que del mismo se haga.
}

que operan más fuertemente sobre los vínculos sociales y los impersonales los que favorecen la consolidación de los poderes de una imagen?

Quisiéramos destacar también el rol integrador que debió comenzar a cumplir la Virgen de Copacabana no ya en términos sociológicos sino a nivel geográfico, a medida que sus prodigios se empezaron a difundir, debido a la comunión de sentimientos y obligaciones que se va creando entre los distintos pueblos que comparten un mismo intercesor divino. Los espacios y fechas significativas que los congregan son ocasiones para trascender los límites y celebrar lo compartido más allá de las diferencias y fricciones. No obstante, este poder unificador de los cultos presenta también sus limitaciones, dadas por las particularidades y localismos que ellos mismos alientan. Es posible, de esta forma, que el efecto no sea "universalizar la devoción", en tanto la adaptación de los recursos eclesiásticos universales a los usos locales implica también rodear de mayor atractivo y santidad a los lugares y tiempos sagrados propios (Christian 1991). En este interés por destacar el propio santuario, una de las principales armas con las que se puede contar son precisamente los milagros. En la órbita católica colonial del s. XVII, esa documentación y proclamación de milagros a la que nos referimos en apartados anteriores, además de propugnar la restauración de la confianza de los fieles contra la incredulidad y los embates de los reformadores, permitía alimentar una importante fuente de orgullo local, por un lado, y al mismo tiempo captar los beneficios de nuevas ofrendas. Atendiendo a este último punto, vemos entonces que además de ser pruebas decisivas del poder de la imagen, sin ellos seguramente los santuarios no hubieran podido atraer la devoción necesaria para su sostenimiento, en tanto los monasterios y conventos de los cuales muchos dependían -como es el caso de Copacabana - recibían gracias a los prodigios una considerable fuente de ingresos. Esto ha podido observarse en varios milagros donde los autores indican cómo los devotos agradecen los favores de la Virgen entregando valiosas ofrendas y limosnas e incluso colaboraciones monetarias para ciertas celebraciones anuales (Calancha 1972 [1639]; Ramos Gavilán 1976[1621]). Siguiendo a Christian (1991), existe una dinámica milagrosa multiplicadora ( milagro $=$ nuevos devotos $=$ nuevos milagros) comprendida y reprodu- 
cida por los fieles a través de sus ofrendas, las cuales tangibilizando el poder milagroso de la imagen actúan como mensajes para los vecinos y favorecen la multiplicación de los devotos.

Finalmente, y desde una perspectiva amplia, creemos que es interesante atender a las correspondencias entre la historia particular de este culto y el "modelo" general de historias de apariciones y devociones marianas vinculado a patrones narrativos españoles. Vemos, por ejemplo, cómo la fama de milagros fue una pieza clave en la construcción de los primeros santuarios americanos y como las narrativas de los prodigios de la Virgen de Copacabana reflejaba la tradición del modelo europeo (Christian 1991; Salles-Reese 1997; Fogelman 2003). La propia efigie de la Virgen, si nos remitimos a su primer milagro, evocaba en la visión que tuvo el religioso franciscano de los rayos de luz que de ella salían, a una tradición iconográfica y exegética del catolicismo occidental que permitió consagrar a esta peculiar imagen local como una nueva hierofanía cristiana. Ello, considerando la identificación -existente ya desde la temprana Edad Media - de la virgen con la mujer que describe el Apocalipsis: "una mujer vestida del Sol, con la Luna debajo de sus pies, y sobre su cabeza una corona de doce estrellas" (Ap. 12: 1; en Salles-Reese 1997). A su vez, esta representación de la madre de Dios condensa símbolos que eran centrales en la iconografía andina tradicional, lo cual nos remite a un nivel aun más general, sobre el cual no avanzaremos aquí pero que muy bien lo aborda Eliade (1954): el de las correspondencias simbólicas universales entre las distintas religiones. Con la intención de profundizar en dichas correspondencias, y avanzar en la definición de pautas y procesos comunes entre distintas historicidades y religiosidades locales, nuestra investigación continuará indagando en el análisis comparativo de otros procesos de construcción y reconstrucción de cultos a imágenes milagrosas.

En Copacabana, el marco estaba dado: una cofradía, una imagen, milagros, un santuario, todos ellos elementos presentes en la mayoría de las historias iniciales de los cultos cristianos. Pero los actores concretos de esta particular historia, dentro del contexto sociohistórico donde se encontraban, fueron imprimiendo un carácter singular a cada uno de ellos: la cofradía podía ser prestigio, la imagen reconocimiento, los milagros aval y aprobación, y el santuario revitalización de antiguas sacralidades. Avanzando un poco en el tiempo, procuraremos seguir la evolución histórica de esta devoción a lo largo de los distintos momentos y coyunturas de los siglos posteriores. Así, por ejemplo, con la consagración de la Virgen de Copacabana como símbolo de la nación boliviana, podremos estudiar también qué actores intervinieron en este proceso, con qué objetivos e intereses y desde qué lugares se siguió reconstruyendo este culto a la "Mamita del Lago".

Agradecimientos Al Dr. Carlos Zanolli, por su lectura crítica y sus valiosas observaciones. A la Dra. Patricia Fogelman, por sus comentarios sobre la primera versión de este trabajo y sus sugerencias bibliográficas.

\section{$*$ Referencias citadas}

ABERCROMBIE, T., 2006. Caminos de la memoria y el poder. Etnografía e historia en una comunidad andina. Instituto Francés de Estudios Andinos-IEB-Asdi, La Paz.

ACOSTA, A. y V. VERGARA, 1999. La lenta estructuración de la Iglesia 1551-1582. En La construcción de la Iglesia en los Andes (s. $X V I-X X)$, F. Armas (Comp.), pp. 33-70. Pontificia Universidad Católica del Perú, Lima.
BÁSCONES, E., 1998. Guía histórica, cultural y religiosa de Copacabanay alrededores. Fraternidad de los Hermanos Menores, Copacabana.

BAUER, B. y C. STANISH, 2001. Ritual and pilgrimage in ancient Andes. University of Texas Press, Austin. 
BOUYSSE-CASSAGNE, T., 1997. De Empédocles a Tunupa: Evangelización, hagiografía y mitos. En Saberes y memorias en los Andes. In Memorian Thierry Saignes, T. Bouisse-Cassagne (Ed.), pp. 157212. Instituto Francés de Estudios Andinos, Lima.

2004. El sol de adentro: Wakas y santos en las minas de Charcas y en el lago Titicaca (s. XV a XVII). Boletín de Arqueología PUCP 8: 59-97.

2007 Ms. Dinámicas culturales y mutaciones históricas en los Andes del Centro-Sur: La invención de la fábula cristiana en los Andes. Seminario de Doctorado, Centro Franco-Argentino de Altos Estudios, Universidad de Buenos Aires, Buenos Aires.

BROW, J., 1990. Notes on community, hegemony, and the uses of the past.Anthropological Quarterly 63 (1): 1-7.

CALANCHA, A. DE LA, 1972 [1639]. Crónicas agustinianas del Perú. Biblioteca "Missionalia Hispánica", vol. XVII. Consejo Superior de Investigaciones Científicas, Instituto "Enrique Florez", Madrid.

CHRISTIAN, W., 1991. Religiosidad local en la España de Felipe II. Nerea, San Sebastián.

COSTILLA, J., 2007. Los usos sociopolíticos del milagro cristiano. Una aproximación teórica y bibliográfica. XI Jornadas Interescuelas/Departamentos de Historia. Universidad Nacional de Tucumán, Tucumán.

2008-2010. Cristianismo indígena en el NOA: Resignificaciones y resimbolizaciones en relatos orales del s. XX (1940-98). Cuadernos del Instituto Nacional de Antropología y Pensamiento Latinoamericano 22: 59-70.

COVARRUBIAS OROZCO, S., 2006 [1611]. Tesoro de la lengua castellana. http://www.cervantesvirtual.com/FichaObra. html?Ref $=18011$.

ELIADE, M., 1954. Mito y realidad. Editorial Labor S.A., Barcelona.

ESPINOZA, W., 1972. Copacabana del Collao. Un documento de 1548 para la etnohistoria andina. Bulletin de l'Institut Français d'Études Andines 1 (1): 1-16

ESTENSSORO, J. C., 2003. Del paganismo a la santidad: La incorporación de los indios del Perú al catolicismo, 1532-1750. Instituto Francés de Estudios Andinos, Lima.

2005. Construyendo la memoria: La figura del Inka y el reino del Perú, de la conquista a Tupac Amaru II. En Los incas, reyes del Perú, T. Cummins (Ed.), pp. 93-173. Banco de Crédito, Lima.
FOGELMAN, P., 2003. Reconsideraciones sobre los orígenes del culto a la Virgen de Luján. Entrepasados 23: 123-148.

GISBERT, T., 1984. El ídolo de Copacabana. La Virgen María y el mundo mítico de los aymara. Yachay 1 (1):25-39.

LÓPEZ, P., 1998. La Aurora en Copacabana. Tesis de Licenciatura en Ciencias Antropológicas, Facultad de Filosofía y Letras, Universidad de Buenos Aires, Buenos Aires.

LORANDI, A. M. y A. E. SCHAPOSCHNIK, 1990. Los milagros de la Virgen del Valle y la colonización de la ciudad de Catamarca. Journal de la Société des Américanistes 76: 177-198.

LUJÁN, F. B., 2002. Nuestra Señora de Copacabana, una devoción andina patrona de Rubielos Altos (Cuenca). Su origen y difusión. Revista Murciana de Antropología 8: 193-246.

MARTÍNEZ, J. L. (Ed.). 2000. Los discursos sobre los otros (una aproximación metodológica interdisciplinaria). Ediciones de la Facultad de Filosofía y Humanidades, Universidad de Chile, Santiago.

MARZAL, M., 1999. La transformación religiosa peruana. En La construcción de la Iglesia en los Andes (s.XVI-XX), F. Armas (Comp.), pp. 143-172. Pontificia Universidad Católica del Perú, Lima.

MUJICA, R., 2001. Rosa limensis. Mística, política e iconografía en torno a la patrona de América. Fondo de Cultura Económica, Lima.

MEDINACELLI, X., 2007. Paullu y manco. ¿Una diarquía inca en tiempos de conquista? Bulletin de l'Institut Français d'Études Andines $36(2): 241-258$.

PLATT, T., T. BOUYSSE-CASSAGNE y O. HARRIS, 2006. Qaraqara-Charka.Mallku-Inkay Rey en la provincia de Charcas (s.XV-XVII). Historia antropológica de una confederación aymara. Instituto Francés de Estudios Andinos, La Paz.

RAMOS, G., 2005. Nuestra Señora de Copacabana ¿devoción india o intermediaria cultural? En Passeurs, mediadores culturales y agentes de la primera evangelización en el mundo ibérico, s. XVI-XIX, S. O'Phelan y C. Salazar (Eds.), pp. 163-179. Pontificia Universidad Católica del Perú, Instituto Francés de Estudios Andinos, Lima.

RAMOS GAVILÁN, A., 1976 [1621]. Historia de Nuestra Señora de Copacabana. Empresa Editora Universo, La Paz.

ROSTWOROWSKI, M., 1986. Estructuras andinas del poder. Ideología religiosa y política. Instituto de Estudios Peruanos, Lima.

SALLES-REESE, V., 1997. From Viracocha to the Virgin of Copacabana. University of Texas Press, Austin. 


\section{Julia Costilla}

SALOMON, F., 1994. La textualización de la memoria en la América andina: Una perspectiva etnográfica comparada.América Indígena $54(4): 229-261$.

VAN DEN BERG, H., 2002. Los milagros de la Virgen de Copacabana en las obras de los agustinos Ramos Gavilán y Antonio De La Calancha.Anuario de la Academia de Historia Eclesiástica 8:33-68.
VILlAREJO, A., 1965. Los agustinos en Perú y Bolivia. Editorial Ausonia, Lima.

WACHTEL, N., 2001. El regreso de los antepasados. Fondo de Cultura Económica, México D.F. 